\title{
Life Cycle Assessment of Ramie Fiber Used for FRPs
}

\author{
Shaoce Dong ${ }^{1}$, Guijun Xian ${ }^{1, *(1)}$ and Xiao-Su Yi ${ }^{2,3}$ \\ 1 School of Civil Engineering, Harbin Institute of Technology (HIT), 73 Hanghe Road, Nangang District, \\ Harbin 150090, China; 18846135354@163.com \\ 2 Faculty of Science \& Engineering, University of Nottingham Ningbo China (UNNC), Ningbo 315000, China; \\ xiaosu.yi@nottingham.edu.cn \\ 3 National Key Laboratory of Advanced Composites, AVIC Composite Technology Center, AVIC Composite \\ Corporation Ltd. (ACC), Beijing 101300, China \\ * Correspondence: gjxian@hit.edu.cn; Tel.: +86-0451-8628-3120
}

Received: 15 June 2018; Accepted: 31 July 2018; Published: 3 August 2018

\begin{abstract}
With the depletion of natural resources and the deterioration of environment, natural fiber based biomaterials are attracting more and more attentions. Natural fibers are considered to be renewable, biodegradable, and ecofriendly, and have been applied to be used as alternative reinforcements to traditional glass fibers for polymer based composites (GFRP). Natural fiber reinforced polymer (NFRP) composites have been found to be manufactured as secondary structures or interior parts of aircrafts or automobiles. In this paper, a cradle-to-gate life cycle assessment (LCA) study was performed to demonstrate the possible advantages of ramie fiber on environmental impacts and to provide fundamental data for the further assessment of ramie fiber reinforced polymers (RFRP) and its structures. By collecting the material inventories of the production process of ramie fiber, the environmental impacts of ramie fiber (characterized by eight main impact categories, which are climate change, terrestrial acidification, freshwater eutrophication, human toxicity potential, ozone depletion, photochemical oxidant creation, freshwater ecotoxicity, and fossil depletion) were calculated and compared with that of glass fiber. Found if spinning process is ignored within the production of the ramie fiber, ramie fiber exhibits better ozone depletion and they have almost the same values of climate change and terrestrial acidification in terms of glass fiber. However, if the spinning process is included, ramie fiber only performs better in terms of ozone depletion. And degumming and carding and spinning processes are the processes that cause more pollution.
\end{abstract}

Keywords: ramie fiber; life cycle assessment; glass fibre; environmental impacts

\section{Introduction}

Fiber reinforced polymers (FRPs) have been widely used in modern industries because of their numerous advantages, like high specific strength and modulus, excellent fatigue performances, resistance to corrosion, and so on. The areas in which FRPs have been applied include aircraft, automotive, marine, sporting goods, infrastructure, and so on [1].

The fiber reinforcements used for FRPs are generally carbon- or glass-fibers. The production of such traditional fibers will bring in high emissions of greenhouse gases and the depletion of raw material natural resources (e.g., fossil fuel). Natural fibers are introduced and used in secondary or decorative structures considering their mechanical properties, because they are considered to be raw materials available, biodegradable, eco-friendly. Recently, natural fibers (e.g., ramie fiber, flax fiber, etc.) have been developed and utilized as a substitute for traditional glass fiber, to serve as fiber reinforcements of FRPs [2-4].

The life cycle assessment (LCA) of FRPs has received extensive attention for a better understanding of the environmental problems of FRPs and its structures. For example, regarding the traditional 
carbon FRPs (CFRPs) and glass FRPs (GFRPs), Foraboschi [5,6] studied the environmental problems of using FRP to strengthen masonry and reinforced concrete (RC) structures. For natural fiber reinforced polymers (NFRPS), there are many LCA studies on various natural fibers. Le Duigou et al. [7], and Summerscales and Dissanayake [8] have studied the environmental problems of flax fiber used in FRPs. Also, a comparative life cycle assessment (LCA) study was done between two bus body components made of hemp fiber reinforced polymers (HFRP) and GFRP [3]. It was found that the hemp-based composites show a lower environmental impact. Furthermore, LCA studies of jute fiber and sisal fiber have also been found $[9,10]$.

In this article, the LCA of another widely used natural fiber, ramie fiber, was studied, because it is one of the best fibers that has better mechanical properties [11] in natural fibers and it can be used in ramie fiber reinforced polymers (RFRP). To the best of our knowledge, research about the environmental problems of ramie fiber is still limited.

Ramie, known as Chinese grass, is a perennial herbaceous plant of the Urticaceae family and it is mainly cultivated in Asia [12]. China contributes more than $90 \%$ of the cultivation of ramie in the world [13]. In Chinese major production areas, ramie can be harvested three times in one year [12]. As ramie fibers are abundant and can meet the requirements of FRP manufacturing, in the European Union's Horizon 2020 research and innovation programme between China and European (Grant No., 690638), ramie fiber was selected to manufacture some of the secondary structures of airports.

In the present study, a cradle-to-gate LCA was performed for the ramie fiber in order to demonstrate the possible advantages of ramie fiber on the environmental impacts and to provide fundamental data for further the assessment of RFRP and its structures. The inventories of the processes, including ramie cultivation, harvesting, peeling, transportation, degumming, and carding and spinning, were collected and calculated. Then, eight environmental categories, namely, climate change, terrestrial acidification, freshwater eutrophication, human toxicity potential, ozone depletion, photochemical oxidant creation, freshwater ecotoxicity, and fossil depletion, were used to characterize the environmental impacts of the ramie fiber. Finally, the environmental impacts of the ramie fiber were compared with that of glass fiber, based on the same mass. A professional LCA software, GaBi, was used to perform the LCA study [14]. The results show that if the spinning process is ignored within the production of the ramie fiber, the ramie fiber exhibits better ozone depletion and they have almost the same values on categories like climate change and terrestrial acidification, in terms of glass fibre. However, if the spinning process is included, the ramie fiber performs only better in term of the ozone depletion. The degumming, and carding and spinning processes are the processes that cause more pollution.

\section{Methodology}

Quantitative LCA was the research methodology that was used in the present study to quantify the environmental performance of the ramie fiber. LCA is an internationally accepted method to assess the environmental impacts of a product or product system. With the collected and/or calculated inputs and outputs of the whole life cycle of a product or product system, LCA can be performed according to some standards (ISO 14040 and ISO $14044[15,16]$ ), in order to evaluate the related environmental impacts quantitatively. A complete LCA study includes four stages, goal and scope definition, life cycle inventory analysis (LCI), life cycle impact assessment (LCIA), and life cycle interpretation [15]. The following explicitly explains the calculation and/or estimation methods used.

\subsection{Goal and Scope Definition}

The goal of an LCA study is related to its intended application and audience, while the scope of an LCA is related to the studied system. The goal of the present study is to get the fundamental data regarding the environmental impacts of ramie fibers. The scope of this study includes ramie cultivation and harvesting, peeling, transportation, degumming, carding and spinning (shown in Figure 1). 


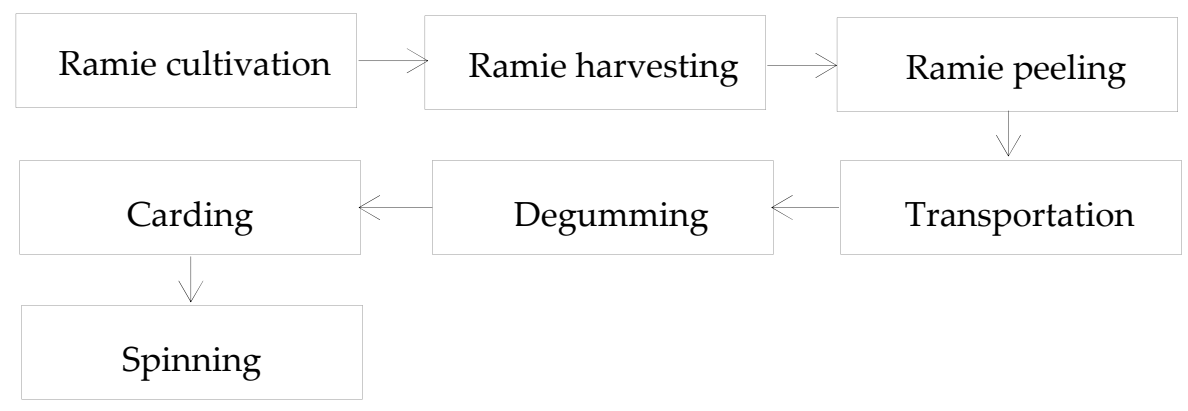

Figure 1. Production processes of ramie fiber.

\subsection{Functional Unit}

The functional unit is specified to provide a reference to which the inputs and outputs are connected. As the specific modulus of the ramie fiber and glass fiber are both $29 \times 10^{5} \mathrm{~m}$ [17], the functional unit was defined as $1000 \mathrm{~kg}$ of ramie fiber, which can offer the same stiffness as glass fiber on a weight-for-weight basis. However, where the composites are concerned, the lower density of the ramie fiber would lead to an increasing use of polymers in the RFRP rather than in the GFRP, if the volume content of polymers in both FRPs is the same.

\subsection{Allocation Principle}

Allocation is very important during the performance of LCA, and different allocation methods and a different set up of the primary products would affect the final environmental burdens of the product or product system studied $[8,18]$. In the present study, the allocation was performed twice based on the mass ratio of primary products to the by-products. At first, the allocation was done in the ramie cultivation, harvesting, and peeling process, where raw ramie fiber was considered as the primary product and the ramie leaves, ramie stalk, and ramie bark (excluding raw ramie fiber) were considered as by-products. Also, in the carding and spinning process, allocation was performed again and long fibers were considered as a primary product, while short fibers and shives were considered as by-products.

The environmental impacts are characterized by eight categories, which are climate change, freshwater eutrophication, ozone depletion, human toxicity, photochemical oxidant creation and terrestrial acidification, freshwater ecotoxicity, and fossil depletion, and were allocated based on the principle stated above.

\subsection{Life Cycle Inventory Analysis}

The life cycle inventory analysis is the second step to complete a LCA. In this step, all of the inputs and outputs related to the processes within the scope need to be collected. According to the scope of the study, the inputs and outputs of the ramie cultivation, harvesting, peeling, transportation, degumming, and spinning processes need to be collected. The data used in this article comes from published papers, theses, websites, and also a ramie textile mill, named Hunan Huansheng Dongting Maye Company Limited, which is located in Yueyang city, Hunan province, China.

\subsubsection{Inputs and Outputs of Ramie Cultivation, Harvesting, and Peeling}

As for the inputs of ramie cultivation, there is no need for seeding after each harvesting, because ramie is a perennial herbaceous plant and cuttage propagation is the main method for planting ramie. Averagely $12.8 \mathrm{~kg} \mathrm{~N}, 3.2 \mathrm{~kg} \mathrm{P}_{2} \mathrm{O}_{5}$, and $16.5 \mathrm{~kg} \mathrm{~K}_{2} \mathrm{O}$ are needed for producing $100 \mathrm{~kg}$ of raw ramie fiber $[19,20]$. To decrease the weeds, $7.5 \mathrm{~kg}$ diuron together with $40 \mathrm{~kg}$ water per hectare [19] are used, and $0.42 \mathrm{~kg}$ cyhalothrin together with $675 \mathrm{~kg}$ water per hectare are assumed to be used for reducing the number of pesticides. It is assumed that a chisel plough was used in winter for weeding once a 
year, and the amount of diesel consumed was set as $8.8 \mathrm{~L} /$ ha [21]. The amount of diesel consumed by agricultural equipment for spraying agrochemicals was set as $1 \mathrm{~L} / \mathrm{ha}$ [21]. It is assumed that no irrigation was applied during the growth of ramie fiber.

Concerning the outputs of ramie cultivation, $3142.9 \mathrm{~kg}$ ramie leaves, $2357.1 \mathrm{~kg}$ ramie stalk, together with $1642.9 \mathrm{~kg}$ ramie bark (including raw ramie fiber) will be obtained when $1000 \mathrm{~kg}$ of raw ramie fiber is obtained [19]. An average value (2337 $\mathrm{kg}$ per year per hectare) of raw ramie fiber yield was set according to the real situation in Hunan province, China, because Hunan province (central area of China) is the main ramie production area in China and the cooperative ramie textile mill is located in Hunan province. Table 1 shows the annual raw ramie yield of Hunan province from 2000 to 2016, with missed data of 2009-2014, which is reported by the ministry of agriculture, China [22]. Moreover, the application of fertilizers will cause emissions of nitrogen gaseous fluxes and nitrogen leaching, which can be estimated according to Intergovernmental Panel on Climate Change (IPCC) tier 1 method [23]. Also, the emission factors of cyhalothrin to air, water, and soil are set as $0.01,0.005$, and 0.013 [24]. Phosphorus leaching was estimated according to the emission factor 0.01 [25]. The emissions of producing fertilizers, pesticide, herbicide, and water were acquired from GaBi databases and the pesticide and herbicide used in GaBi software to compute the environmental impacts were an unspecific type.

Table 1. Yields of ramie fiber of 2000-2016 with missed data of 2009-2014 in Hunan province.

\begin{tabular}{cccccccccccc}
\hline Year & 2000 & 2001 & 2002 & 2003 & 2004 & 2005 & 2006 & 2007 & 2008 & 2015 & 2016 \\
\hline Yield/kg & 1964 & 2002 & 2359 & 2304 & 2443 & 2541 & 2516 & 2494 & 2502 & 2297 & 2285 \\
\hline
\end{tabular}

The emissions from producing and the combustion of diesel are the main causes for environmental pollution in the ramie harvesting process. A 4 LMZ 160 crawler-type ramie harvester with $25.7 \mathrm{~kW}$ auxiliary power was used for harvesting the ramie fiber and its average harvesting rate is 0.15 hectare per hour [26]. When the consumption of diesel used for harvesting was computed, the specific fuel consumption was set as $0.2448 \mathrm{~kg} / \mathrm{kW} \cdot \mathrm{h}$, according to the data sheet of T35 type of diesel engine (whose power is $24 \mathrm{~kW}$ ) of Changchai Company Limited [27]. As for diesel combustion, the emission factors of carbon monoxide, carbon dioxide, nitrogen oxides, sulfur dioxide, and non-methane volatile organic compounds (NMVOC) were set as $0.0291 \mathrm{~g} / \mathrm{kg}, 3.04 \mathrm{~g} / \mathrm{kg}, 0.0571 \mathrm{~g} / \mathrm{kg}, 0.00415 \mathrm{~g} / \mathrm{kg}$, and $0.00916 \mathrm{~g} / \mathrm{kg}$, respectively [24].

As for the peeling process, generating electricity is the main reason accounting for emissions to the natural environment. A 6BZ-400 model ramie barker was assumed to peel the bark from the ramie stem, and its auxiliary power and peeling rate are $2.8 \mathrm{~kW}$ and $10 \mathrm{~kg} / \mathrm{h}$. The emissions of generating electricity were taken from GaBi.

An allocation was performed during this process based on the mass of raw ramie fiber, ramie leaves, ramie stalk, and ramie barks (excluding raw ramie fiber) and $14 \%$ of the environmental burdens were assigned to raw ramie fiber. The allocation was performed with the help of GaBi software. The biogenetic carbon storage of the ramie fiber was also considered in this work. The amount of carbon stored by the natural fiber depends on its cellulose content [28]. The degummed ramie fiber mainly consists of cellulose, and according to the literature [28], and when $1 \mathrm{~kg}$ of natural fiber is produced, $1.5 \mathrm{~kg} \mathrm{CO} 2$ would be absorbed.

Table 2 summarizes the inputs and outputs of producing $1000 \mathrm{~kg}$ of raw ramie fiber. 
Table 2. Inputs and output of producing $1000 \mathrm{~kg}$ of raw ramie fiber.

\begin{tabular}{cccc}
\hline Input & Quantity & Output & Quantity \\
\hline $\begin{array}{c}\text { Ammonium nitrate } \\
(33.5 \% \mathrm{~N})\end{array}$ & $382.1 \mathrm{~kg}$ & Raw ramie fiber & $1000 \mathrm{~kg}$ \\
Triple superphosphate & $69.6 \mathrm{~kg}$ & Ramie bark \\
$\left(46 \% \mathrm{P}_{2} \mathrm{O}_{5}\right)$ & $275 \mathrm{~kg}$ & (excluding raw ramie fiber) & $642.9 \mathrm{~kg}$ \\
Potassium chloride & $9.6 \mathrm{~kg}$ & Ramie leaf \\
$\left(60 \% \mathrm{~K}_{2} \mathrm{O}\right)$ & $0.5 \mathrm{~kg}$ & Ramie stalk & $3142.9 \mathrm{~kg}$ \\
Diuron & $917.8 \mathrm{~kg}$ & Carbon monoxide & $2357.1 \mathrm{~kg}$ \\
Cyhalothrin & Carbon dioxide & $1.7 \mathrm{~g}$ \\
Water & $58 \mathrm{~kW} \cdot \mathrm{kg}$ & Nitrous oxide & $176.5 \mathrm{~g}$ \\
Electricity & $1500 \mathrm{~kg}$ & Nitrogen oxides & $5.4 \mathrm{~kg}$ \\
Diesel & Sulfur dioxide & $3.3 \mathrm{~g}$ \\
& & Emission of cyhalothrin to air & $0.2 \mathrm{~g}$ \\
Sequestered atmospheric $\mathrm{CO}_{2}$ & & Emission of cyhalothrin to water & $2.5 \mathrm{~g}$ \\
& & Emission of cyhalothrin to soil & $6.5 \mathrm{~g}$ \\
& & Phosphate to water & $0.14 \mathrm{~kg}$ \\
& & NMVOC & $0.5 \mathrm{~g}$ \\
\hline
\end{tabular}

This table does not include the inputs of the ramie rootstock and soil components consumed, which are about four tons. NMVOC-non-methane volatile organic compounds.

\subsubsection{Inputs and Outputs of Transportation}

The GaBi software contains almost all of the transport modes. In the present paper, the transportation process was modeled with GaBi. The transportation distance between the ramie field and the manufacturing factory is assumed as $50 \mathrm{~km}$. A Euro 5 diesel truck with a 3.3 ton payload capacity was set to be the transportation method, considering the yield of the ramie fiber. Although the distance from field to factory is difficult to determine precisely, the environmental impacts of this process contribute very little to the overall environmental impacts, which can be seen from later parts.

\subsubsection{Inputs and Outputs of Degumming Process}

Because there are gummy matters (20-40\% of the mass of raw ramie fiber), mainly composed of hemicellulose and pectin in raw ramie fibers [29], the raw ramie fiber cannot be used directly in FRPs until they are degummed. Degumming methods mainly include chemical, enzymatic, and microbial methods [30], and in the present study, enzymes together with chemicals (shown in Figure 2) were used to get the degummed fiber in this study.

The inputs of the degumming process were the chemicals (shown in Table 3) used to dissolve and remove the gummy matters, which were collected from the cooperative company mentioned above. It is known that, when $100 \mathrm{~kg}$ of raw ramie fibers were degummed, $60 \mathrm{~kg}$ degummed ramie fiber would be obtained, and $11 \mathrm{~kg}$ sulphuric acid, $20.25 \mathrm{~kg}$ sodium hydroxide, $2.4 \mathrm{~kg}$ hypochlorous, and $1.4 \mathrm{~kg}$ degumming agent would be consumed. The emissions for producing the chemicals used in this process were taken from the GaBi databases, except for degumming agent because of commercial confidentiality. As the dosage of the degumming agent is usually very small, the environmental impacts of producing and using the degumming agent have not been taken into consideration in this study. The environmental impacts of producing enzymes were not included in this paper, because of a lack of reliable data. A lack of data regarding the environmental impacts of hypochlorous acid, when the GaBi model was built, led to the use of calcium hypochlorite in order to produce hypochlorous acid, according to a chemical reaction among calcium hypochlorite, carbon dioxide, and water.

The outputs of the degumming process were mainly wastewater and it mainly comes from the pickling, boiling, washing, and bleaching processes. The wastewater from ramie degumming process usually has high $\mathrm{pH}$ value, high contents of chemical oxygen demand (COD), and biochemical oxygen demand (BOD). The wastewater cannot be discharged directly until it has been well treated. In this study, the wastewater treatment method was set based on the literature [31], in which a acidifying hydrolysis/biological oxidation/photochemical process method was utilized in a sewage treatment 
plant to make the wastewater meet the requirements of the national sewage discharge standard in China. To run the whole treatment process, electricity and chlorine need to be supplied constantly and the environmental impacts of producing electricity and chlorine were also within the system boundary in the present study. After treatment, the contents of COD, BOD, and sulfide were set as $300 \mathrm{mg} / \mathrm{L}$, $100 \mathrm{mg} / \mathrm{L}$ according to the national wastewater discharge standard in China.

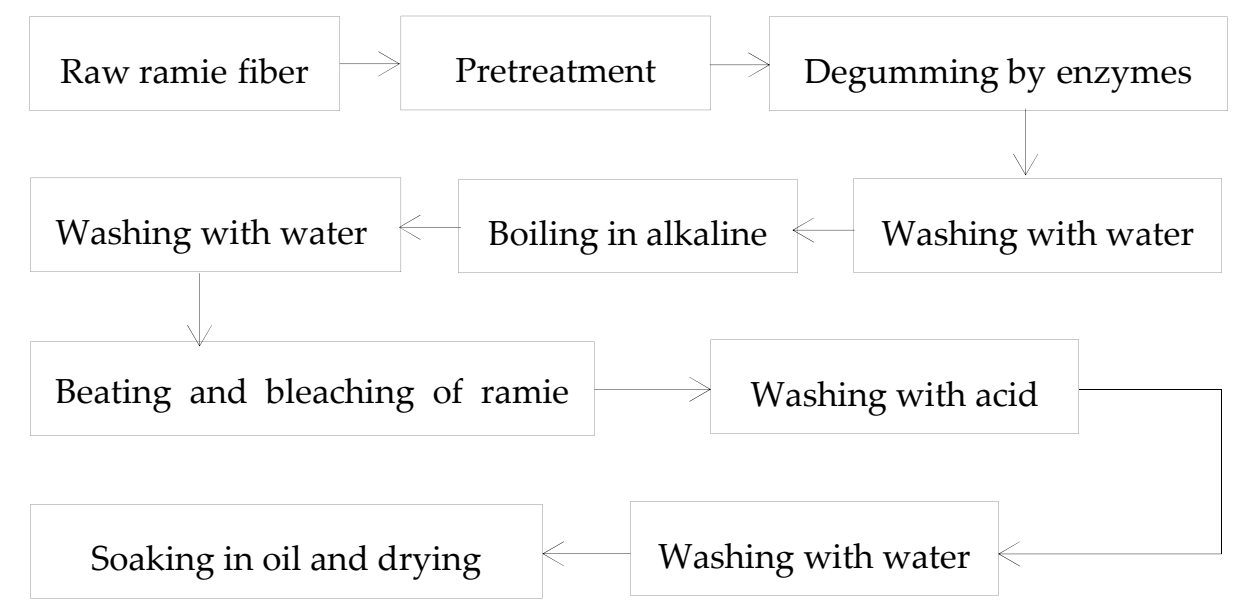

Figure 2. Typical enzymatic degumming processes of ramie fiber.

Table 3 shows the inputs and outputs for producing $1000 \mathrm{~kg}$ of degummed ramie fiber and the emissions of producing water, electricity, chlorine, sulphuric acid, and sodium hydroxide were taken from GaBi software.

Table 3. Inputs and outputs of producing $1000 \mathrm{~kg}$ of degummed ramie fiber. COD—chemical oxygen demand; BOD—biochemical oxygen demand.

\begin{tabular}{cccc}
\hline Input & Quantity & Output & Quantity \\
\hline Water & $733 \mathrm{tons}$ & Degummed ramie fiber & $1000 \mathrm{~kg}$ \\
Electricity & $1475.52 \mathrm{~kW} \cdot \mathrm{h}$ & Pectin, lignin, and hemicellulose & $666.7 \mathrm{~kg}$ \\
Chlorine & $8.8 \mathrm{~kg}$ & Wastewater (treated) & 733 tons \\
Sulphuric acid & $183.3 \mathrm{~kg}$ & COD & $300 \mathrm{mg} / \mathrm{L}$ \\
Sodium hydroxide & $337.5 \mathrm{~kg}$ & BOD & $100 \mathrm{mg} / \mathrm{L}$ \\
Hypochlorous acid & $40.0 \mathrm{~kg}$ & & \\
Ramie degumming agent & $23.3 \mathrm{~kg}$ & & \\
Steam from biomass & $16.7 \mathrm{tons}$ & & \\
Raw ramie fiber & $1666.7 \mathrm{~kg}$ & & \\
\hline
\end{tabular}

\subsubsection{Inputs and Outputs of Carding and Spinning Process}

Degummed ramie fibers could be spun to get yarns, which were used to for the comparison to glass filaments. Before spinning, carding is necessary to get long degummed ramie fibers suitable for spinning, and short fibers and shives that could be used in other ways like building particle boards or animal beddings. Therefore, the allocation was performed again in this stage, based on the mass of long fibers and others. Based on the data from the cooperative factory, only $30 \%$ of the degummed fibers will be formed into yarns. The electricity consumption for the carding and spinning are based on the data for the flax fiber carding and spinning [21], because of no reliable data are available for ramie carding and spinning. Table 4 shows the inputs and outputs of the ramie carding and spinning process. 
Table 4. Inputs and outputs of producing $1000 \mathrm{~kg}$ ramie yarns.

\begin{tabular}{cccc}
\hline Input & Quantity & Output & Quantity \\
\hline Electricity & $7260 \mathrm{~kW} \cdot \mathrm{h}$ & Ramie yarns & $1000 \mathrm{~kg}$ \\
Degummed ramie fiber & $3333.3 \mathrm{~kg}$ & Short fibers and shives & $2333.3 \mathrm{~kg}$ \\
\hline
\end{tabular}

\subsection{Life Cycle Impact Assessment (LCIA)}

In the LCIA stage, the emissions and resource extraction will be translated into several environmental impact scores by multiplying the corresponding characterization factors. There are mainly two types of characterization factors, which are at a midpoint level and endpoint level, respectively.

In this paper, the ReCiPe method was chosen to model the environmental impacts of different fibers with the help of GaBi software. The environmental impact categories used to characterize the overall environmental performance of every fiber are climate change, terrestrial acidification, freshwater eutrophication, ozone depletion, human toxicity, photochemical oxidants creation, freshwater eco-toxicity, and fossil depletion.

The inputs and outputs of the processes involved in the scope of this study were used to build models in GaBi software.

\subsection{Interpretation}

Interpretation was the final step of an LCA study, and by interpretating the results from LCIA stage, the processes that have a high potential for pollution would be identified, and some useful conclusions and recommendations can be made.

\section{Results and Discussions}

Using the inputs and outputs from the LCI stage, the ReCiPe method and the eight main environmental categories to characterize the environmental performance of the ramie fiber, the LCIA results are shown in Table 5 and Figure 3.

Table 5. Life cycle impact assessment (LCIA) results of one ton ramie yarns, ramie fiber (after carding), and glass fibers.

\begin{tabular}{|c|c|c|c|c|}
\hline Environmental Impact Category & Unit & Glass Fibers & $\begin{array}{c}\text { Ramie Fiber } \\
\text { (after Carding) }\end{array}$ & Ramie Yarns \\
\hline Climate change & $\mathrm{kg} \mathrm{CO}$-Equiv. & 1740 & 1770 & 3790 \\
\hline Freshwater eutrophication & kg P eq. & $5.25 \times 10^{-3}$ & $86.9 \times 10^{-3}$ & $87.1 \times 10^{-3}$ \\
\hline Ozone depletion & kg CFC-11 eq. & $483 \times 10^{-10}$ & $7.88 \times 10^{-10}$ & $8.26 \times 10^{-10}$ \\
\hline Human toxicity potential & kg 1,4-DB eq. & 20.8 & 147 & 175 \\
\hline Fossil depletion & kg oil eq. & 578 & 832 & $1.34 \times 10^{3}$ \\
\hline
\end{tabular}

As can be seen from Table 5 and Figure 3, when the environmental burdens of the ramie yarns were compared to that of the glass fibers, the ramie yarns only performed better in terms of ozone depletion, with a reduction rate of $98.29 \%$. However, as for the other categories, the glass fibers are more eco-friendly compared with the ramie yarns. When the environmental performance of the ramie fibers (after carding and without spinning) are compared to that of the glass fibers, the ramie fibers (after carding and without spinning) perform better on ozone depletion, with a reduction rate of $98.37 \%$, and it has almost the same values for climate change and terrestrial acidification compared to glass fiber. 
Concerning identifying the processes that contribute the most to the overall environment pollution, as can be seen Table 6 and Figure 4, the degumming process and carding and spinning process are the main causes for massive environmental pollution. The percentages of the degumming process and spinning and carding process that contributes to climate change, terrestrial acidification, freshwater eutrophication, ozone depletion, human toxicity, photochemical oxidant formation, freshwater ecotoxicity, and fossil depletion is $65.2 \%$ and $58.3 \%, 76.9 \%$ and $20.4 \%, 74.2 \%$ and $0.28 \%, 94.3 \%$ and $5.05 \%, 81.4 \%$ and $17.5 \%, 79.2 \%$ and $18.8 \%, 68.7 \%$ and $0.95 \%$, and $53.7 \%$ and $41.1 \%$, respectively. The cultivation, harvesting, and peeling processes mainly contribute to freshwater eutrophication, ozone depletion, and freshwater ecotoxicity, and the negative value caused by these processes are due to the absorption of carbon dioxide. The transportation process contributes little to all eight of these categories, compared to other processes.

Table 6. Values of the eight categories contributed by different production processes of ramie yarns.

\begin{tabular}{cccccc}
\hline $\begin{array}{c}\text { Environmental } \\
\text { Impact Category }\end{array}$ & Unit & Transportation & $\begin{array}{c}\text { Cultivation, } \\
\text { Harvesting and } \\
\text { Peeling }\end{array}$ & $\begin{array}{c}\text { Carding and } \\
\text { Spinning }\end{array}$ & Degumming \\
\hline Climate change & $\mathrm{kg} \mathrm{CO}_{2}$-Equiv. & 31 & -921 & 2210 & 2400 \\
\hline Terrestrial acidification & $\mathrm{kg} \mathrm{SO}$ eq. & 0.024 & 0.346 & 2.74 & 4.94 \\
\hline $\begin{array}{c}\text { Freshwater } \\
\text { eutrophication }\end{array}$ & $\mathrm{kg} \mathrm{P} \mathrm{eq.}$ & $5.9 \times 10^{-5}$ & 0.0125 & $24.1 \times 10^{-5}$ & 0.027 \\
\hline Ozone depletion & $\mathrm{kg} \mathrm{CFC-11} \mathrm{eq.}$ & 0 & $5.30 \times 10^{-12}$ & $41.7 \times 10^{-12}$ & $738 \times 10^{-12}$ \\
\hline $\begin{array}{c}\text { Human toxicity } \\
\text { potential }\end{array}$ & $\mathrm{kg} \mathrm{1,4-DB} \mathrm{eq.}$ & 0 & 1.8 & 30.6 & 63 \\
\hline $\begin{array}{c}\text { Photochemical oxidant } \\
\text { formation }\end{array}$ & $\mathrm{kg} \mathrm{NMVOC}$ & 0.0431 & 0.353 & 2.7 & 4.39 \\
\hline Freshwater ecotoxicity & $\mathrm{kg}$ 1,4-DB eq. & $1.25 \times 10^{-11}$ & 1.26 & 0.0395 & 2.51 \\
\hline Fossil depletion & $\mathrm{kg}$ oil eq. & 1.4 & 67.6 & 550 & 701 \\
\hline
\end{tabular}

From the results above, it seems that the environmental performance of ramie fiber is not so competitive compared with glass fiber, especially when the spinning process was included into the whole manufacturing system of the ramie fiber. However, this idea may not be true. Because, at first, compared with the manufacturing technology of glass fiber, the production techniques of the ramie fiber are still not perfect and there is still a lot of room for improvement in the production techniques of ramie fiber. Then, there are no production techniques just for RFRP. For example, during the degumming process of the ramie fiber, when ramie fibers are used in FRPs, there may be no need for bleaching, which will reduce the consumption of sodium hypochlorite, washing water, and the releasing of treated wastewater. Then, the residual gum rate of the degummed ramie fiber should be less than $2 \%$ in the textile industry, while in the FRPs, the residual gum rate may be not so strict, which means that less chemicals may be used in the degumming process. Next, the spinning requirements for the textiles and FRPs may be different too. Finally, ramie fibers can degrade automatically, which can reduce the energy required for handling the disposals made of RFRP.

Based on the discussion above, more research should be performed to establish the manufacturing technologies of the ramie fiber just for RFRP. Degumming and spinning processes are the main processes that can be targeted to decrease the environmental burdens of ramie fibers used for FRPs.

Although some results have been obtained, there are also some limitations in this article. Firstly, the data used in the calculation is relatively limited, which means there will be more uncertainty regarding the final results. Then, data from the cooperative ramie textile mill was collected by the local workers in the mill, because of commercial confidentiality, which means there may be some variation because they know nothing about LCA principles. However, this study did provide some useful information and conclusions in general. 


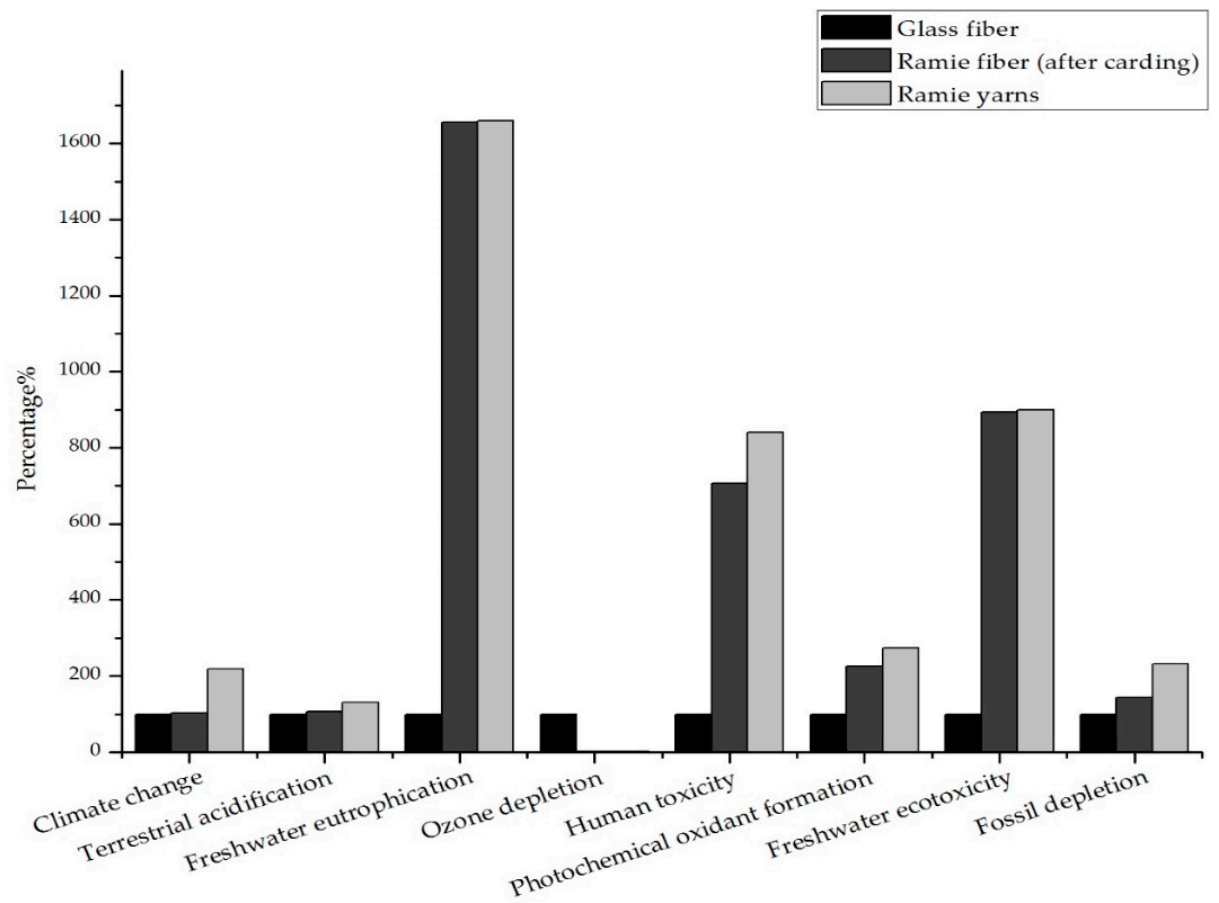

Figure 3. Comparison between three different kinds of fibers in terms of the eight main environmental categories.

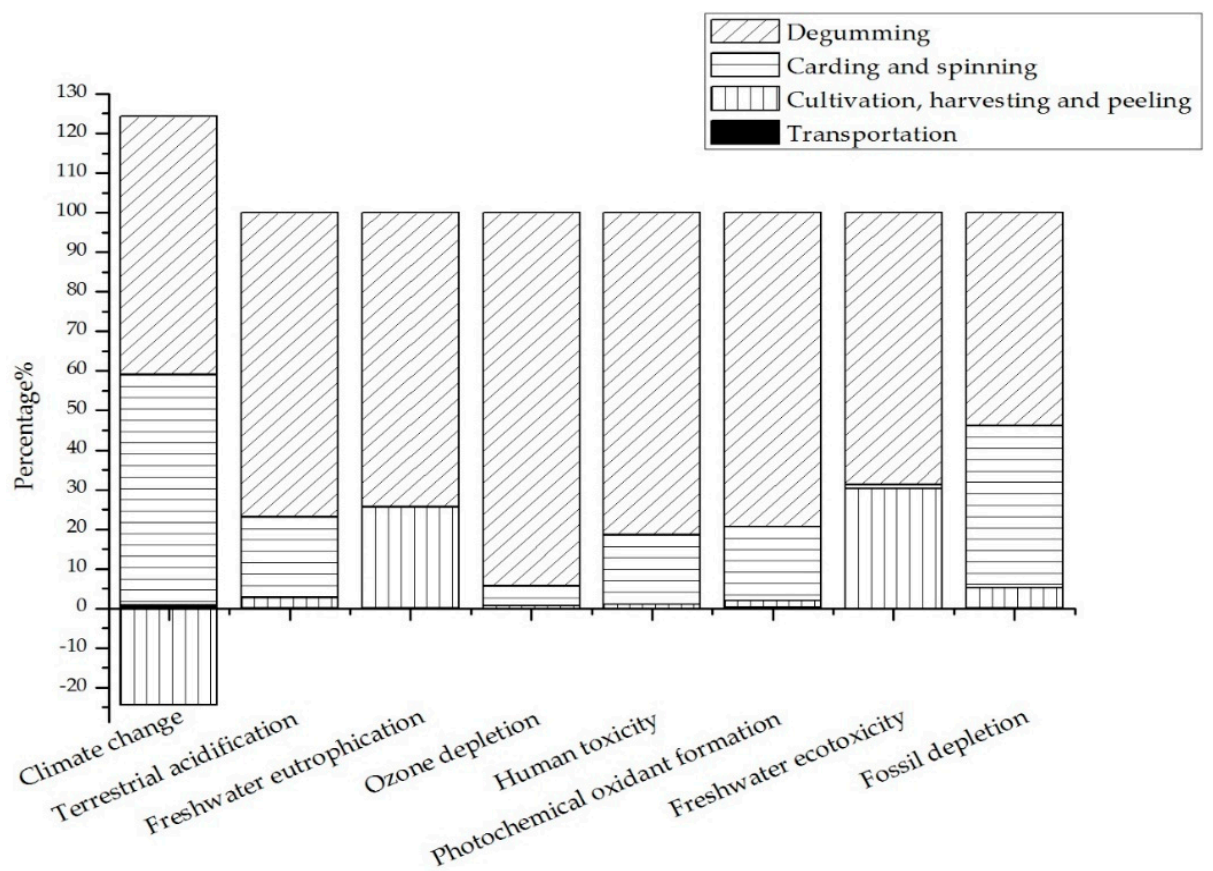

Figure 4. Percentages of different processes that contribute to the eight different environmental impact categories of ramie yarns.

\section{Conclusions}

According to LCA, the input and output data of the production processes of ramie fibers were summarized and analyzed. The comparison of LCA between the ramie fibers and glass fibers were performed. The following conclusions can be drawn based on the above study. 
According to the results of LCA, if the spinning process was included within the manufacturing of the ramie fiber, the ramie fiber performs better than glass fiber only in ozone depletion. If the spinning process was not included, the ramie fiber performs better in the ozone depletion and has almost the same values of climate change and terrestrial acidification.

The degumming, and carding and spinning processes are the main causes of pollution during the production of ramie fibers. The cultivation, harvesting, and peeling processes mainly contribute to the categories of freshwater eutrophication, ozone depletion, and freshwater ecotoxicity. The transportation process contributes little to the overall pollution.

More research should be done toward developing production techniques for the ramie fibers for the RFRP.

Author Contributions: G.X. and X.-S.Y. conceived and guided the study; S.D. collected the data and wrote the paper.

Funding: This work was financially supported by the Chinese MIIT Special Research Plan on Civil Aircraft, grant No. MJ-2015-H-G-103 and European Union's Horizon 2020 research and innovation programme, under grant agreement No. 690638.

Conflicts of Interest: The authors declare no conflict of interest.

\section{References}

1. Mallick, P.K. Fiber-Reinforced Composites: Materials, Manufacturing, and Design, 3rd ed.; CRC Press: Boca Raton, FL, USA; London, UK; New York, NY, USA, 2007; ISBN 9780849342059-CAT\# 4205.

2. Wötzell, K.; Wirth, R.; Flake, M. Life cycle studies on hemp fibre reinforced components and ABS for automotive part. Die Angew. Makromol. Chem. 1999, 272, 121-127. [CrossRef]

3. Schmehl, M.; Müssig, J.; Schönfeld, U.; Von Buttlar, H.B. Life Cycle Assessment on a Bus Body Component Based on Hemp Fiber and PTP. J. Polym. Environ. 2008, 16, 51-60. [CrossRef]

4. Scarponi, C.; Messano, M. Comparative evaluation between E-Glass and hemp fiber composites application in rotorcraft interiors. Compos. Part B Eng. 2015, 69, 542-549. [CrossRef]

5. Foraboschi, P. Analytical model to predict the lifetime of concrete members externally reinforced with FRP. Theor. Appl. Fract. Mech. 2015, 75, 137-145. [CrossRef]

6. Foraboschi, P. Effectiveness of novel methods to increase the FRP-masonry bond capacity. Compos. Part B Eng. 2016, 107, 214-232. [CrossRef]

7. Le Duigou, A.; Davies, P.; Baley, C. Environmental impact analysis of the production of flax fibres to be used as composite material reinforcement. J. Biobased Mater. Bioenergy 2011, 5, 153-165. [CrossRef]

8. Summerscales, J.; Dissanayake, N.P.J. Allocation in the life cycle assessment (LCA) of flax fibres for the reinforcement of composites. In Proceedings of the 21st International Conference on Composite Materials, Xi'an, China, 20-25 August 2017.

9. Islam, M.S.; Ahmed, S.K. The impacts of jute on environment: An analytical review of Bangladesh. J. Environ. Earth Sci. 2012, 2, 24-32.

10. Broeren, M.L.M.; Dellaert, S.N.C.; Cok, B.; Patel, M.K.; Worrell, E.; Shen, L. Life cycle assessment of sisal fibre-Exploring how local practices can influence environmental performance. J. Clean. Prod. 2017, 149, 818-827. [CrossRef]

11. Saheb, D.N.; Jog, J.P. Natural fiber polymer composites: A review. Adv. Polym. Technol. 1999, 18, 351-363. [CrossRef]

12. Liu, F.; Liu, Q.; Liang, X.; Huang, H.; Zhang, S. Morphological, anatomical, and physiological assessment of ramie [Boehmeria nivea (L.) Gaud.] tolerance to soil drought. Genet. Resour. Crop. Evol. 2005, 52, 497-506. [CrossRef]

13. Bo, W.; Dingxia, P.; Lijun, L.; Zhenxia, S.; Na, Z.; Shimei, G. An effcient adventitious shoot regeneration system for ramie (Bohehmeria nivea Gaud) using thidiazuron. Bot. Study 2007, 48, 173-180.

14. Thinkstep GaBi. Available online: www.gabi-software.com (accessed on 24 April 2018).

15. ISO 14040:2006 Environmental Management-Life Cycle Assessment-Principles and Framework. Available online: www.iso.org (accessed on 24 April 2018). 
16. ISO 14044:2006 Environmental management-Life cycle Assessment-Requirements and Guidelines. Available online: www.iso.org (accessed on 24 April 2018).

17. Paul, W.; Ivens, J.; Ignaas, V. Natural fibres: Can they replace glass in fibre reinforced plastics? Compos. Sci. Technol. 2003, 63, 1259-1264.

18. Ekvall, T.; Finnveden, G. Allocation in ISO 14041-A critical review. J. Clean. Prod. 2001, 9, $197-208$. [CrossRef]

19. Ramie Institute of Hunan Agricultural University. Available online: http://chinagrass.hunau.edu.cn/ (accessed on 24 April 2018).

20. Wang, C.T.; Li, Z.D.; Yu, T.W.; Liu, M.S.; Xiao, Z.P.; Cui, G.X.; Xue, N.D.; Li, G.S.; Deng, M.Q. Fertilization programma in ducing fine quality and high yield of ramie and its application technique. J. Hunan Agric. Coll. 1994, 20, 318-324.

21. Dissanayake, N.P.J. Life Cycle Assessment of Flax Fibres for the Reinforcement of Polymer Matrix Composites. Ph.D. Thesis, University of Plymouth, Plymouth, UK, May 2011.

22. Ministry of Agriculture of the People's Republic of China. Available online: www.moa.gov.cn (accessed on 24 April 2018).

23. 2006 IPCC Guidelines for National Greenhouse Gas Inventories_Volume 4-Agriculture, Forestry and Other Land Use. Available online: www.ipcc-nggip.iges.or.jp/public/2006gl/index.html (accessed on 24 April 2018).

24. EU Concerted Action Report Harmonization of Environmental Life Cycle Assessment for Agriculture Final Report. Concerted Action AIR3-CT94-2028. Available online: www.researchgate.net (accessed on 24 April 2018).

25. Bioenergy for Europe: Which One Fits Best? A Comparative Analysis for the Community. Available online: https: / www.researchgate.net/publication/320258744_Bioenergy_for_Europe_Which_Ones_Fit_ Best_-_A_Comparative_Analysis_for_the_Community (accessed on 24 April 2018).

26. Huang, J.C.; Li, X.W.; Zhang, B.; Tian, K.P.; Shen, C.; Wang, J.G. Research on the 4LMZ160 crawler ramie combine harvester. J. Agric. Mech. Res. 2015, 9, 155-158. [CrossRef]

27. Changchai Company Limited's Product Sheet. Available online: http://www.changchai.com.cn/show.asp? $\mathrm{id}=18$ (accessed on 24 April 2018).

28. Benoît, C.; Xavier, P.; André, G.; Fritz, S.; Gérard, C. Contributions of hemicellulose, cellulose and lignin to the mass and the porous properties of chars and steam activated carbons from various lignocellulosic precursors. Bioresour. Technol. 2009, 100, 292-298.

29. Shengwen, D.; Zhengchu, L.; Xiangyuan, F.; Ke, Z.; Lifeng, C.; Xia, Z. Diversity and characterization of ramie-degumming strains. Sci. Agricola 2011, 69, 119-125.

30. Deb, P.R.; Pratik, S.; Sabyasachi, M.; Pradipta, B.; Rakesh, K.G. Degumming of ramie: Challenge to the queen of fibres. Int. J. Bioresour. Sci. 2014, 1, 37-41.

31. Bao, H.F.; Bao, J.G.; Li, H.W. Treatment of ramie retting wastewater using acidifying hydrolysis/biological oxidation/photochemical process. China Water Wastewater 2006, 22, 52-55.

(c) 2018 by the authors. Licensee MDPI, Basel, Switzerland. This article is an open access article distributed under the terms and conditions of the Creative Commons Attribution (CC BY) license (http:/ / creativecommons.org/licenses/by/4.0/). 